\title{
Destruction of 2,4,6-Trinitrotoluene using Ammonium Peroxydisulfate
}

\author{
John F. Cooper \\ Francis Wang \\ Thomas Shell \\ Ken King
}

RECEIVED

AUG 201996

OSTI

July 1996

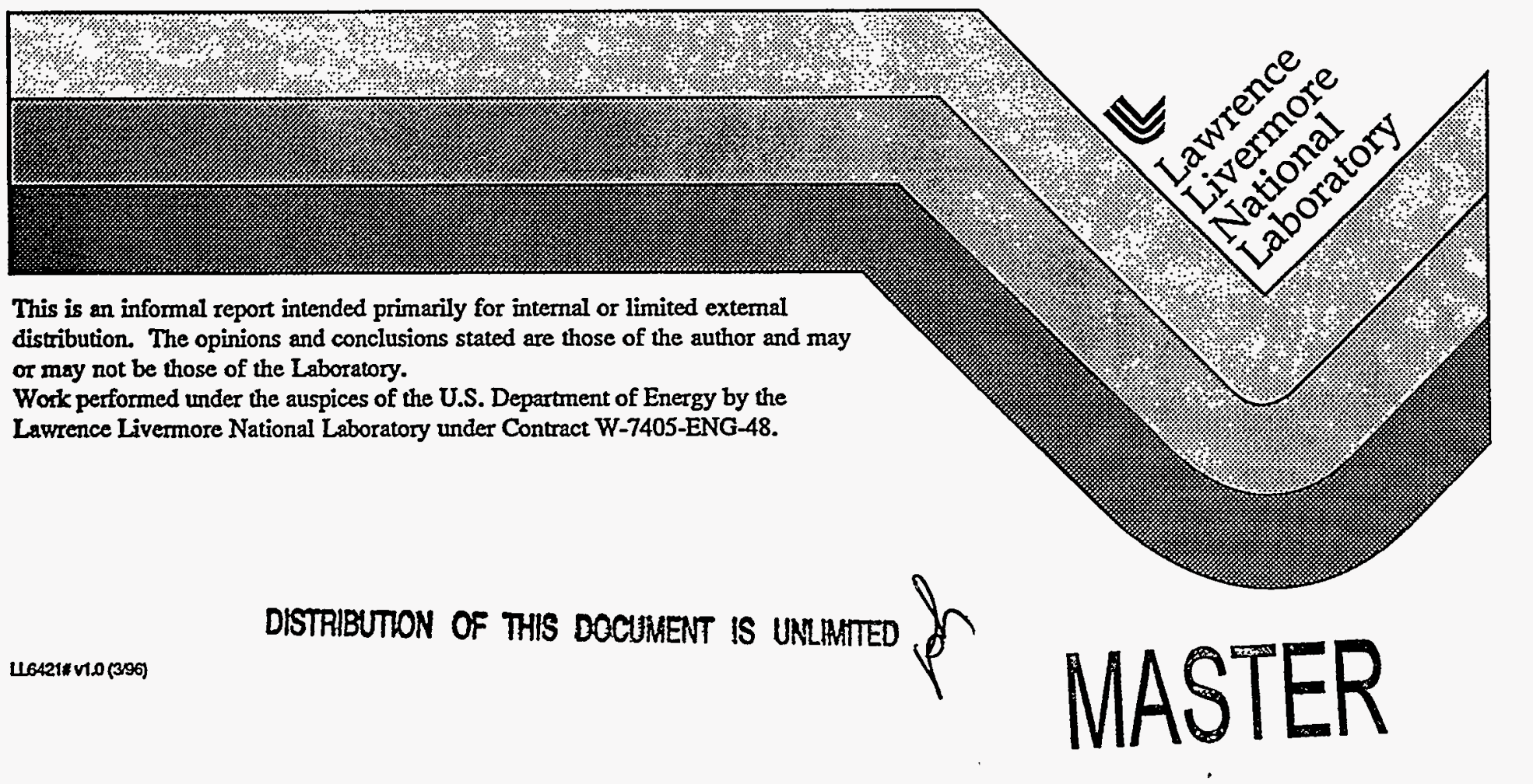




\section{DISCLAIMER}

This document was prepared as an account of work sponsored by an agency of the United States Government. Neither the United States Government nor the University of California nor any of their employees, makes any warranty, express or implied, or assumes any legal liability or responsibility for the accuracy, completeness, or usefulness of any information, apparatus, product, or process disclosed, or represents that its use would not infringe privately owned rights. Reference herein to any specific commercial products, process, or service by trade name, trademark, manufacturer, or otherwise, does not necessarily constitute or imply its endorsement, recommendation, or favoring by the United States Government or the University of California. The views and opinions of authors expressed herein do not necessarily state or reflect those of the United States Government or the University of California, and shall not be used for advertising or product endorsement purposes.

This report has been reproduced directly from the best available copy.

Available to DOE and DOE contractors from the Office of Scientific and Technical Information P.O. Box 62, Oak Ridge, TN 37831

Prices available from (615) 576-8401, FTS 626-8401

Available to the public from the National Technical Information Service

U.S. Department of Commerce 5285 Port Royal Rd., Springfield, VA 22161 


\section{DISCLAIMER}

Portions of this document may be illegible in electronic image products. Images are produced from the best available original document. 


\section{Destruction of 2,4,6-Trinitrotoluene using Ammonium Peroxydisulfate}

by

John F. Cooper, Francis Wang, Thomas Shell, and Ken King

Department of Chemistry and Materials Science - Lawrence Livermore National Laboratory

Abstract

TNT was destroyed in a small batch reactor, using uncatalyzed $4 \mathrm{~N}$ ammonium peroxydisulfate at $95^{\circ} \mathrm{C}$. The material was destroyed below limit of detection in less than 15 minutes, indicating a formal first order rate constant of $0.06 \mathrm{~min}^{-1}$ : A crude estimate of scaleup rates indicates a throughput of 1 tonne/ $\mathrm{m}^{3}$-day.

Experimental. Tests were conducted on the oxidative destruction of 2,4,6-trinitrotoluene using uncatalyzed $4 \mathrm{~N}$ ammonium peroxydisulfate at $95 \mathrm{C}$. A 1-L batch reactor vessel with reflux column was loaded with $100 \mathrm{ml}$ of $0.1 \mathrm{M} \mathrm{H}_{2} \mathrm{SO}_{4}$ and preheated to $95^{\circ} \mathrm{C}$. One gram $(1 \mathrm{~g})$ of granular TNT was injected; the TNT immediately melted to form a dispersion of fine globules.

Using a peristaltic pump, $4 \mathrm{~N}$ (NH4)2S2O8 was introduced at a rate of $5.5 \pm 0.5 \mathrm{ml} / \mathrm{minute}$. After 10 minutes, the TNT separate phase had vanished, and a sample was taken, chilled, and analyzed for total carbon using a calibrated TOC machine. The experiments were repeated twice, with oxidant injection terminated after 15 and 30 minutes, and residuals analyzed as before.

The peroxydisulfate concentration was determined by reduction by excess $\mathrm{Fe}$ (II), followed by titration with a standardized solution of $0.1 \mathrm{~N} \mathrm{KMnO}_{4}$. The TOC was calibrated using $25 \mathrm{ppm}$ solutions of sucrose.

Results and analysis. TNT has a molecular weight of $227.13 \mathrm{~g} / \mathrm{mol}$, a weight fraction of carbon of 0.37 , and an equivalent weight of 6.31 g/equiv, based on the stoichiometry oxidation half reaction:

$$
\mathrm{C}_{7} \mathrm{H}_{5}\left(\mathrm{NO}_{2}\right)_{3}+17 \mathrm{H}_{2} \mathrm{O}=7 \mathrm{CO}_{2}+3 \mathrm{HNO}_{3}+36 \mathrm{H}^{+}+36 \mathrm{e}^{-}
$$

Initially $1 \mathrm{~g}$ (0.159 equivalents) were added to $100 \mathrm{ml}$ of acid, thus producing a carbon concentration of $3627 \mathrm{ppm}$ (as C) and a total amount of carbon of $0.37 \mathrm{~g}$ in the vessel. After 10 minutes, $55 \mathrm{ml}$ of oxidant were added (containing 0.22 equivalents), the TNT separate phased had vanished, and analysis of the product showed $0.045 \mathrm{~g}$ of carbon remaining in the solution, or $87.7 \%$ destroyed--an apparent oxidant utilization of $63 \%$. After 15 minutes of oxidation, the carbon content of the resultant liquid fell below the limit of the TOC analyzer $(\sim 0.5 \mathrm{ppm})$, or $<2$ $\mathrm{ppm}$ when corrected for dilution prior to test, with an apparent utilization of oxidant of $0.159 / 0.33=48 \%$. This indicates that more than $99.9 \%$ of the material had been destroyed in 15 minutes at $95^{\circ} \mathrm{C}$ by $4 \mathrm{~N}$ peroxydisulfate, with a utilization of between 48 and $63 \%$.

We can calculate a formal rate constant, based on the assumption of first-order reaction kinetics. Using concentrations expressed in equivalents, the rate constant is

$$
\mathrm{k}_{\mathrm{a}} \sim(0.159 * 0.877 / 0.22) / 10=0.06 \mathrm{~min}^{-1}
$$

This value is in the midpoint of values measured for destruction of bulk ethylene glycol, triethylamine, oxalic acid, etc. , and supports the general model that uncatalyzed peroxydisulfate oxidation is controlled by the thermal decomposition of the oxidant to form the sulfate radical 
anion. [1-3]. The Attached chart shows the rate superimposed on data for trace-level organic compounds as well as data taken from destruction of bulk organic compounds, with rates extrapolated from rate data for formation of the free radical.

Projections of throughput. We can make a crude estimate of the throughput of a waste destruction technique, simply by scaling the rate data to a $1 \mathrm{~m}^{3}$ vessel fed with $4 \mathrm{~N}$ oxidant and TNT. Based on this rate, the projected throughput of the process (using $4 \mathrm{~N}$ ammonium peroxydisulfate, $50 \%$ utilization) is roughly 1.1 tonne $/ \mathrm{m}^{3} /$ day, as computed from:

$$
\text { throughput } \sim 50 \% * 0.06 \mathrm{~min}^{-1} * 4 \text { equiv/L } * 6.3 \mathrm{~g} / \text { equiv }=0.756 \mathrm{~g}-\mathrm{TNT} / \mathrm{L}-\mathrm{min}
$$

Table 1. Destruction of $1 \mathrm{~g}$ of TNT in experiments lasting 10,15, and 30 minutes, using $4 N$ ammonium peroxydisulfate (uncatalyzed) at $95^{\circ} \mathrm{C}$.

\begin{tabular}{|c|c|c|c|c|c|}
\hline $\begin{array}{c}\text { Time } \\
\text { min }\end{array}$ & $\begin{array}{c}\text { oxidant added } \\
\text { equiv }\end{array}$ & $\begin{array}{c}\text { total } \\
\text { weight, } g\end{array}$ & $\begin{array}{c}\text { ppm-C } \\
\text { determined }\end{array}$ & $\begin{array}{c}\text { carbon } \\
\text { remaining, } g\end{array}$ & $\begin{array}{c}\text { Fraction } C \\
\text { destroyed }\end{array}$ \\
\hline 0 & 0 & $102 \mathrm{~g}$ & 3627 & 0.37 & $(0)$ \\
\hline 10 & 0.22 & 168 & 269 & 0.045 & 0.877 \\
\hline 15 & 0.33 & 201 & $<2^{*}$ & $<0.0004$ & $>0.999$ \\
\hline 30 & 0.66 & 301 & $<2^{*}$ & $<0.0006$ & $>0.998$ \\
\hline
\end{tabular}

*below limit of detection, corrected for dilution of aliquot; actual measurement $0.19 \mathrm{ppm}, 30$ minutes.

Acknowledgments

We are grateful for the sponsorhip of the Mixed Waste Focus Group, U.S. Department of Energy. We also gratefully acknowledge the technical advise of Phil Pagoria and coordinating support of César Pruneda, both of LLNL's high explosives facility (HEF).

\section{References}

1. John F. Cooper, Francis Wang, Roger Krueger, Ken King, Joseph C. Farmer, and Martyn Adamson, "Destruction of organic wastes by ammonium peroxydisulfate with electrolytic regeneration of the oxidant," UCRL-JC-121979 Rev.2 April 1996.

2. John F. Cooper, Roger Krueger and Joseph C. Farmer, "Destruction of VX by aqueousphase oxidation using peroxydisulfate: Direct chemical oxidation," (Proc. Workshop on Advances in Alternative Demilitarization Technologies, pp. 429-442; Reston VA September 25-7 1995; published by SAIC Aberdeen, MD)

3. John F. Cooper, Francis Wang, Roger Krueger, Ken King, Thomas Shell, Joseph C. Farmer, and Martyn Adamson, "Demonstration of omnivorous non-thermal mixed waste treatment: Direct chemical oxidation using peroxydisulfate," First Quarterly Report to Mixed Waste Focus Group, SF2-3-MW-35 October - December 1995; UCRL-ID-123193, February 1996.

4. Beylerian, N. M. and Khachatrian, A. G., J. Chem. Soc. Perkin Trans. II 1984 1937-1941.

5. Gary R. Peyton, "The free-radical chemistry of persulfate-based total organic carbon analyzers," Marine Chemistry $41,91-103$ (1993). 


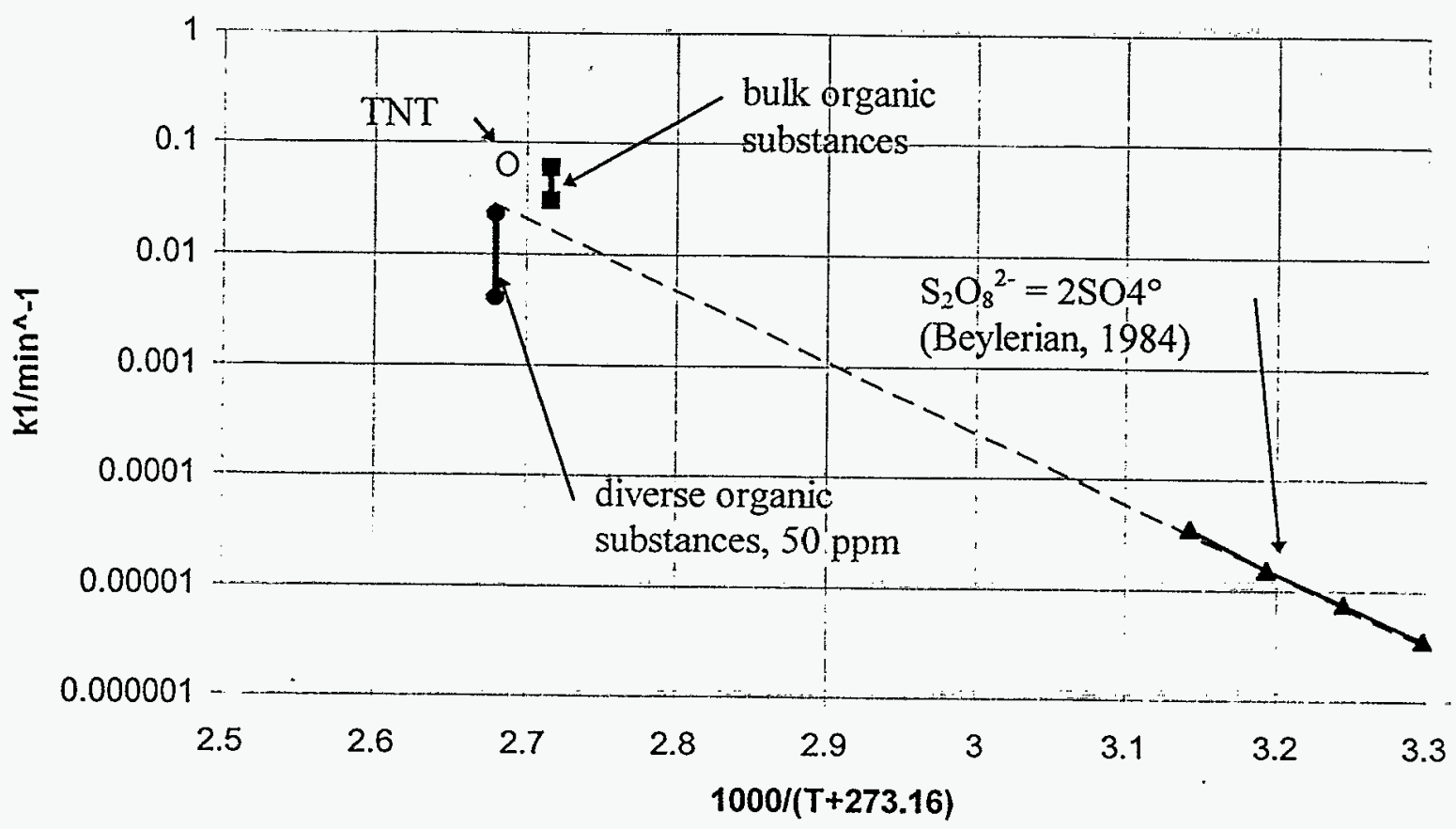

Figure 1. Given are rates of destruction of 20 diverse organic substances at trace levels, TNT at bulk concentrations $1 \%$ (circle), and other test chemicals (ref [1]) are plotted against reciprocal absolute temperature. The rate of formation of the sulfate free radical from uncatalyzed thermal decomposition of peoxydisulfate are also given, supporting the theory that peoxydisulfate destruction of organic compounds is determined by the initial formation of the sulfate radical anion $[4,5]$. 